\title{
Hypertension in Pregnancy
}

\section{Magnesium intoxication in women with preeclampsia with severe features treated with magnesium sulfate}

\author{
Muhammad Ilham Aldika Akbar, Daniel Yoseph, Aditiawarman -, \\ Muhammad Adrianes Bachnas, Erry Gumilar Dachlan, Gustaaf Albert \\ Dekker \& Ernawati
}

To cite this article: Muhammad Ilham Aldika Akbar, Daniel Yoseph, Aditiawarman -, Muhammad Adrianes Bachnas, Erry Gumilar Dachlan, Gustaaf Albert Dekker \& Ernawati (2020): Magnesium intoxication in women with preeclampsia with severe features treated with magnesium sulfate, Hypertension in Pregnancy, DOI: 10.1080/10641955.2020.1754851

To link to this article: https://doi.org/10.1080/10641955.2020.1754851

$$
\text { 曲 Published online: } 25 \text { Apr } 2020 .
$$

Submit your article to this journal $\widetilde{ }$

View related articles

View Crossmark data $\rtimes$ 


\title{
Magnesium intoxication in women with preeclampsia with severe features treated with magnesium sulfate
}

\author{
Muhammad Ilham Aldika Akbar (10,b,c, Daniel Yoseph ${ }^{\mathrm{b}}$, Aditiawarman -a,b, Muhammad Adrianes Bachnas (1) , \\ Erry Gumilar Dachlan ${ }^{\mathrm{a}, \mathrm{b}, \mathrm{c}}$, Gustaaf Albert Dekker ${ }^{\mathrm{a}, \mathrm{e}}$, and Ernawati (1) ${ }^{\mathrm{a}, \mathrm{b}, \mathrm{c}}$
}

\begin{abstract}
aDepartment Obstetrics and Gynecology, Faculty of Medicine, Universitas Airlangga, Surabaya, Indonesia; ${ }^{b}$ Department Obstetrics and Gynecology, DR. Soetomo General Academic Hospital, Surabaya, Indonesia; 'Department Obstetrics and Gynecology, Universitas Airlangga Hospital, Surabaya, Indonesia; 'Department Obstetrics and Gynecology, Dr. Moewardi General Hospital, Faculty of Medicine Universitas

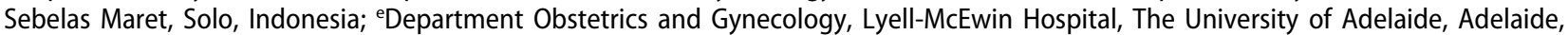
Australia
\end{abstract}

\begin{abstract}
Objective: To evaluate the maternal-neonatal outcome in magnesium (Mg)-intoxicated women with preeclampsia with severe features (PESF) treated with magnesium sulfate $\left(\mathrm{MgSO}_{4}\right)$.

Methods: A total of $19 \mathrm{Mg}$ intoxicated PESF women (cases) were compared with 166 PESF women without signs of intoxication (controls).

Results: $\mathrm{Mg}$ serum levels of cases was higher compared to control group $(12.36 \pm 3.54 \mathrm{mg} / \mathrm{dl}$ versus $2.69 \pm 0.83 \mathrm{mg} / \mathrm{dl}$ ). 3 women died and 3 had major maternal morbidity in cases group compared with zero in the control group $(P=0.009)$. Mg intoxication was also significantly associated with perinatal deaths and low Apgar scores at 1 and 5 minutes.

Conclusion: $\mathrm{Mg}$ intoxication is associated with a increased risk of maternal and perinatal mortality and morbidity.
\end{abstract}

ARTICLE HISTORY

Received 13 November 2019

Accepted 7 April 2020

\section{KEYWORDS}

Magnesium intoxication;

hypermagnesemia;

magnesium sulfate;

preeclampsia with severe

features

\section{Introduction}

Preeclampsia (PE) is a life-threatening syndrome in pregnancy characterized by the new onset of hypertension after 20 weeks of gestational age and accompanied by proteinuria or other signs of organ involvement (1). PE is one of the main problems in pregnancy, causing maternal mortality and morbidity in low and middle-income countries (Duley et al., 1992). About 50,000-63,000 women die each year of PE/eclampsia. Indonesia, the fourth most populous country in the world with a population of 267 million, is a middle-income country with PE incidence of $5-7 \%$. The maternal $(2.2 \%)$ and perinatal mortality rate (12\%) of PE are still high (2). A large segment of the Indonesian population still faces poverty, has lack of access to health care, and often receives inadequate treatment in primary health-care centers. The wrong financial incentives under the current Indonesian universal health coverage system are partially to blame for too late referrals (3).

Magnesium sulfate $\left(\mathrm{MgSO}_{4}\right)$ is recommended unanimously by all major guidelines as a first-choice agent to prevent eclamptic seizures and is used worldwide (4). The Magpie trial, the large international multicenter randomized controlled trial (RCT), reported that the use of $\mathrm{MgSO}_{4}$ reduces the risk of eclampsia about $58 \%$ in women with $\mathrm{PE}$ compared with $\mathrm{PE}$ women receiving placebo (5). $\mathrm{MgSO}_{4}$ as an anticonvulsant agent works through multiple mechanisms: inhibits seizure excitability in the cerebral cortex, inhibits the N-methyl-D-aspartate receptor in the hippocampus, and calcium metabolism in the neuromuscular junction. $\mathrm{MgSO}_{4}$ also works as a potent vasodilator, especially in the cerebral vasculature, potentially reducing brain ischemia-hypoxia in preeclamptic women (6). Although $\mathrm{MgSO}_{4}$ has been proven to be effective in preventing eclampsia, its use still contains a small but definitive risk of magnesium intoxication or hypermagnesemia (7-9).

$\mathrm{Mg}$ intoxication is clinically evident when serum $\mathrm{Mg}$ levels exceed $12 \mathrm{mg} / \mathrm{dL}$ (hypermagnesemia), which almost exclusively occurs in PE women with marked renal involvement or in women receiving higher $\mathrm{MgSO}_{4}$ infusion rates (10). The main symptoms of $\mathrm{Mg}$ intoxication are the result of its general CNS depressant effects, peripheral depression affecting muscle contractility, and central neuromuscular transmission blockade. Clinical manifestation of $\mathrm{Mg}$

CONTACT Ernawati $\otimes$ ernawati.spog@gmail.com $\Theta$ Department Obstetrics \& Gynecology, Faculty of Medicine, Universitas Airlangga, RSUD Dr. Soetomo, RS UNAIR, Indonesia 
intoxication seldom occurs until magnesium levels reach a total dosage beyond $12 \mathrm{mg} / \mathrm{dL}$ in maternal blood. Clinical manifestations of $\mathrm{Mg}$ intoxication include general weakness, double vision, low blood pressure, loss of conscious and respiratory distress. The lethal manifestation, cardiac arrest, may happen if $\mathrm{Mg}$ concentration rises above $30 \mathrm{mg} / \mathrm{dL}(8,11,12)$.

Hypertension in pregnancy, especially PESF is in the top three diagnosis of the sickest high-risk obstetrics cases in Dr. Soetomo General Academic Hospital, the main tertiary referral hospital in Surabaya, Indonesia $(13,14)$. Intravenous $\mathrm{MgSO}_{4}$ is administrated routinely in PESF without measurements of $\mathrm{Mg}$ levels unless there are clinical indications (suspicion $\mathrm{Mg}$ intoxication) due to lack of adequate hospital funding under the Indonesian national insurance system.

In this study, we evaluated the incidence of $\mathrm{Mg}$ intoxication in women with $\mathrm{PESF}$ receiving $\mathrm{MgSO}_{4}$ and investigated its association with adverse maternal and perinatal outcomes.

\section{Material and methods}

This study was conducted in Dr. Soetomo Hospital, the major tertiary referral center in East-Java, Indonesia, from January 2014 - December 2018; all women with PESF receiving Mg with clinical signs and symptoms of $\mathrm{Mg}$ intoxication and confirmed hypermagnesemia (cases $\mathrm{n}=19)$ were compared to 166 PESF patients (8 controls per case) also treated with $\mathrm{Mg}$ but without signs of $\mathrm{Mg}$ intoxication (control group). The historical control group was recruited randomly with 33-34 patients each year to achieve a balanced distribution (2014-2018). Since Mg levels are not routinely checked in our hospital in PESF patients receiving $\mathrm{MgSO}_{4}, \mathrm{Mg}$ levels in this study were only measured in women with signs or symptoms of $\mathrm{Mg}$ intoxication. In the control group, 24 random women out the 166 also had a $\mathrm{Mg}$ level measured. $\mathrm{Mg}$ level was measured using the Calmagite Colorimetric method (Hardness reagen set).

PE was defined using ISSHP classification: hypertension developing after 20 weeks gestation and the existence of one or more of the following: proteinuria, other maternal organ dysfunction (renal insufficiency, liver involvement, neurological complications, hematological complications), and uteroplacental dysfunction. HELLP syndrome was defined as a combination of hemolysis (lactic dehydrogenase $>1000 \mathrm{U} / \mathrm{L}$, schistocytes in blood smear), elevated liver enzymes, and thrombocytopenia (platelet count $<100.000 \mathrm{u} / \mathrm{L}$ ) in PE women. PESF was defined as PE with any of the following findings: systolic blood pressure $>160 \mathrm{mmHg}$ or diastolic blood pressure $>110 \mathrm{mmHg}$ on two occasions at least 4 hours apart, thrombocytopenia, elevated liver enzymes (AST $>45 \mu / \mathrm{L}, \mathrm{ALT}>35 \mu / \mathrm{L}$ ), progressive renal insufficiency (BUN $>20 \mathrm{mg} / \mathrm{dL}$, serum kreatinin $>1.1 \mathrm{mg} / \mathrm{dL}$ ), pulmonary edema, and cerebral or visual disturbances. Pulmonary edema was defined based on symptoms of shortness of breath/ difficulty breathing, physical examination, and confirmed with a chest X-ray (15). Hypertensive crisis was defined as systolic blood pressure more than $180 \mathrm{mmHg}$ and/or diastolic blood pressure more than $120 \mathrm{mmHg}(1,4,16,17)$.

Every patients with PESF in our hospital received $\mathrm{MgSO}_{4}$, using the Zuspan regimen consisting of a loading dose $4 \mathrm{~g}$ in $20 \mathrm{ml}$ (20\% solution) administered iv over 15-20 minutes, followed by a maintenance dose of $1 \mathrm{~g}$ /hour iv infusion using syringe pump from admission until 12 hours or 24 hours after delivery in case of eclampsia (18). In preterm PESF women managed conservatively, $\mathrm{MgSO}_{4}$ is administered the first 24 hours following admission. In these women, $\mathrm{MgSO}_{4}$ is discontinued during their observation period and started again at the time of delivery. On the other hand, the regimen mostly used in primary health-care centers consists of a modified Pritchard scheme; loading dose of 4 gram $20 \%$ iv $\mathrm{MgSO}_{4}$ in $10-15$ minutes and 10 gram IM ( 5 gram in each buttock), followed by maintenance dose 5 gram $\mathrm{IM} \mathrm{MgSO}_{4}$ in alternate buttock for every 6 hours (19).

Cases of $\mathrm{Mg}$ intoxication were identified as women who received $\mathrm{MgSO}_{4}$ treatment and had documented clinical signs of magnesium intoxication in addition to serum magnesium levels $>12 \mathrm{mg} / \mathrm{dL}$. Clinical signs and symptoms included muscles weakness, loss of deep tendon reflexes, respiratory paralysis, ECG changes (prolonged PR interval and widened QRS complex), SA or AV node block, loss of consciousness or cardiac arrest.

The primary outcomes of the study were maternal and perinatal outcomes among the 19 cases compared with the 166 controls. The maternal parameters evaluated included maternal age, body mass index (BMI), parity, referral origin, antenatal history, $\mathrm{PE}$ type. Maternal outcomes included mode of delivery, gestational age at delivery, laboratory results, maternal complications, and maternal death. PE complications included any of the following: eclampsia, HELLP syndrome, pulmonary edema, hypertensive crisis, acute kidney injury. The definition of maternal death in this study was any death during the treatment in hospital, and not necessarily a direct effect of $\mathrm{Mg}$ intoxication. Perinatal outcomes included fetal sex, birth weight, Apgar scores (minutes 1 \& 5), SGA (<10th population birth weight centile), and perinatal death. 
The results were analyzed using chi-square test, independent t-test, Mann Whitney test, and Fisher exact test where appropriate. Statistical measurement was performed using IBM SPSS Statistics for Windows, Version 25.0. Armonk, NY: IBM Corp. Released 2017.

\section{Results}

\section{Incidence of $\mathrm{Mg}$ intoxication in women with PESF}

The incidence of PESF during the period 2014-2018 was 1743 cases out of a total of 6823 total deliveries (25.54\%); Mg intoxication was diagnosed in 19 patients (1.09\%). The annual incidence of $\mathrm{Mg}$ intoxication over this 5 -year period varied between $0.6 \%$ and $1.5 \%$.

\section{Maternal characteristics}

The overall characteristics between the two groups were quite similar (Table 1) except the origin of the cases. All $\mathrm{Mg}$ intoxicated cases were referred from other hospitals or primary health-care centers compared with $80.2 \%$ in the control group: $19.8 \%$ women in the control group had regular antenatal care in our hospital (booked case). Twelve (63.2\%) cases with $\mathrm{Mg}$ intoxication were referred from distant rural areas. There was no significant difference in maternal age, BMI, parity, and PE type between both groups.

\section{Maternal outcomes}

The clinical manifestations of $\mathrm{Mg}$ intoxication were varied: $42.1 \%$ of women demonstrated muscle weakness (loss of patellar reflex), 10.5\% respiratory depression, and $42.1 \%$ loss of consciousness. The maternal outcomes of cases versus controls are presented in Table 2. The mode of delivery between both groups was not different, most patients in both groups were delivered by cesarean section.

The rate of maternal mortality and severe morbidities was higher among cases compared with the controls; 14 out of the 19 cases (73\%) had a major complication, including 3 maternal deaths compared with $30.7 \%$ major complication rate in the control group (OR 2.85; 95\% CI 2.12-3.82). Eclampsia and HELLP syndrome were the main complications found in the case group. Interestingly we found no pulmonary edema among the cases compared with $13(7.8 \%)$ in the control group.

Importantly, the three maternal deaths were not directly caused by the actual $\mathrm{Mg}$ intoxication but were related to other complications such as septic shock, thyroid crisis, and intracerebral hemorrhage. Laboratory manifestations reflecting disease severity were significantly worse in the case group (protein urine, LDH, ALT, AST, BUN, SK, and Albumin).

A subgroup analysis was performed in PESF control women who had their serum $\mathrm{Mg}$ levels measured (Table 3). The Mg level among the cases was markedly elevated compared with controls $(12.36 \pm 3.45$ versus $2.69 \pm 0.83 \mathrm{mg} / \mathrm{dL} ; p<0.001)$. The minimum and maximum level of both groups were as follows: cases (8.9-25.6 mg/dL) versus controls $(1.5-4.3 \mathrm{mg} / \mathrm{dL})$. In addition, we found a significant difference in the total $\mathrm{Mg}$ dose, length, and method of $\mathrm{Mg}$ administration between the groups. A significantly higher proportion of cases received $>24 \mathrm{~g}$ of $\mathrm{Mg}$, and had $\mathrm{Mg}$ administered for $>24$ hours, and had $\mathrm{Mg}$ administered by intramuscular injection. As high as $21.1 \%$ of cases had oliguria.

\section{Perinatal outcomes}

Maternal Mg intoxication had a significant association with worse perinatal outcomes: lower 1 and 5 minute

Table 1. Maternal characteristics of PESF patients treated with Mg with (cases) and without Mg intoxication (controls).

\begin{tabular}{|c|c|c|c|c|}
\hline & $\begin{array}{c}\text { Cases } \\
\mathrm{n}=19\end{array}$ & $\begin{array}{l}\text { Controls } \\
n=166\end{array}$ & $p$ value & $\begin{array}{c}\text { OR } \\
(95 \% \mathrm{Cl})\end{array}$ \\
\hline Maternal Age & $28.83+6.191$ & $31.96+6.769$ & 0.415 & NA \\
\hline BMI & $30.9875+8.694$ & $30.6698+7.210$ & 0.973 & NA \\
\hline \multicolumn{5}{|l|}{ Parity } \\
\hline Primipara & $4(21.2 \%)$ & $51(31.1 \%)$ & \multirow[t]{2}{*}{0.349} & \multirow[t]{2}{*}{ NA } \\
\hline Multipara & $15(78.9 \%)$ & $115(68.9 \%)$ & & \\
\hline \multicolumn{5}{|l|}{ Referral origin } \\
\hline Country & 12 (63.2\%) & $42(25.5 \%)$ & \multirow[t]{2}{*}{$0.001^{*}$} & 5.02 \\
\hline The City & $7(36.8 \%)$ & $124(74.5 \%)$ & & $(1.85-13.59)$ \\
\hline \multicolumn{5}{|l|}{ Booked Case } \\
\hline No & 19 (100\%) & $134(80.2 \%)$ & \multirow[t]{2}{*}{$0.005^{*}$} & 9.72 \\
\hline Yes & 0 & $32(19.8 \%)$ & & $(0.57-165.03)$ \\
\hline \multicolumn{5}{|l|}{ PE type } \\
\hline Early onset PE & $14(73.6 \%)$ & $104(62.7 \%)$ & \multirow[t]{2}{*}{0.314} & \multirow[t]{2}{*}{ NA } \\
\hline Late onset PE & $5(26.4 \%)$ & $62(37.3 \%)$ & & \\
\hline
\end{tabular}


Table 2. Maternal outcomes of cases versus controls.

\begin{tabular}{|c|c|c|c|c|}
\hline & $\begin{array}{c}\text { Cases } \\
\mathrm{n}=19\end{array}$ & $\begin{array}{l}\text { Controls } \\
\mathrm{n}=166\end{array}$ & $p$ value & $\begin{array}{c}\text { OR } \\
(95 \% \mathrm{Cl})\end{array}$ \\
\hline GA at delivery & $31.63 \pm 3.51$ & $33.81 \pm 3.33$ & $0.014^{*}$ & NA \\
\hline \multicolumn{5}{|l|}{ Mode of delivery } \\
\hline CS & $11(57.9 \%)$ & $110(66.3 \%)$ & \multirow[t]{2}{*}{0.473} & \multirow[t]{2}{*}{ NA } \\
\hline Vaginal delivery & $8(42.1 \%)$ & $56(33.7 \%)$ & & \\
\hline \multicolumn{5}{|l|}{ Complication } \\
\hline Yes & $14(73.7 \%)$ & $51(30.7 \%)$ & \multirow[t]{2}{*}{$0.0002^{*}$} & \multirow{11}{*}{$\begin{array}{c}2.85 \\
(2.12-3.82) \\
\text { NA }\end{array}$} \\
\hline No & $5(26.3 \%)$ & $115(69.3 \%)$ & & \\
\hline Complication type & 14 & 51 & \multirow[t]{9}{*}{$0.0113^{*}$} & \\
\hline Eclampsia & $6(42.9 \%)$ & $9(17.6 \%)$ & & \\
\hline HELLP Syndrome & $3(21.4 \%)$ & $11(21.6 \%)$ & & \\
\hline Pulmonary edema & 0 & $13(25.5 \%)$ & & \\
\hline IUGR & $1(7.1 \%)$ & $4(7.8 \%)$ & & \\
\hline IUFD & $3(21.5 \%)$ & $1(2 \%)$ & & \\
\hline Multiple complication & 0 & $9(17.6 \%)$ & & \\
\hline Emergency Hypertension & 0 & $1(2 \%)$ & & \\
\hline Acute Kidney Injury & $1(7.1 \%)$ & $3(5,9 \%)$ & & \\
\hline \multicolumn{5}{|l|}{ Maternal death } \\
\hline Yes & $3(15.8 \%)$ & 0 & \multirow[t]{2}{*}{$0.009^{*}$} & \\
\hline No & $16(84.2 \%)$ & $166(100 \%)$ & & \\
\hline BUN & $33.75+20.56$ & $10.93+8.84$ & $0.000^{*}$ & \\
\hline Serum Creatinine & $2.61+1.68$ & $0.65+0.07$ & $0.000^{*}$ & \\
\hline Serum Albumin & $2.64+0.38$ & $2.58+0.55$ & $0.000^{*}$ & \\
\hline ALT & $59.58+94.79$ & $43.35+12.72$ & $0.057^{*}$ & \\
\hline AST & $96.68+203.56$ & $21.25+3.8$ & $0.000^{*}$ & \\
\hline \multicolumn{3}{|l|}{ Protein Urine } & \multirow[t]{6}{*}{$0.024^{*}$} & \multirow[t]{6}{*}{ NA } \\
\hline$(-)$ & 0 & $3(1.8 \%)$ & & \\
\hline+1 & $1(5.3 \%)$ & $20(12.1 \%)$ & & \\
\hline+2 & $1(5.3 \%)$ & 56 (33.9\%) & & \\
\hline+3 & $10(52.6 \%)$ & $55(33.3 \%)$ & & \\
\hline$\geq 4$ & $7(36.8 \%)$ & 31 (18.8\%) & & \\
\hline
\end{tabular}

Table 3. Subgroup analysis of cases vs controls group.

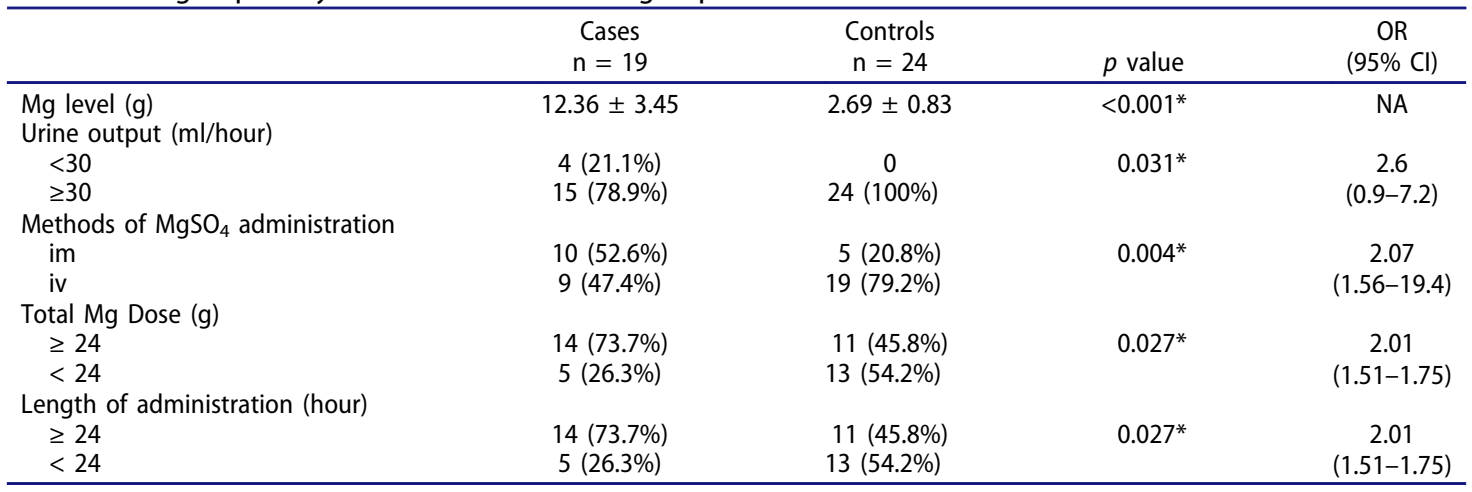

Apgar scores, lower birth weights, and a higher SGA and perinatal death rate (Table 4). The perinatal death rate in the case group was $36.8 \%$ compared with $6.6 \%$ in the control group.

\section{Discussion}

The results of this study confirm that while the incidence of $\mathrm{Mg}$ intoxication in women with PESF treated with $\mathrm{MgSO}_{4}$ is quite low (1,09\%), $\mathrm{Mg}$ intoxication is associated with significantly increased adverse maternal and perinatal outcomes. The incidence of Mg intoxication in a large systematic review involving 9556 women, was $1.3-1.6 \%$ (8). Duley et al., in another large metaanalytic study, also found that $\mathrm{Mg}$ intoxication was rare and only occurred in around $1 \%$ of women receiving $\mathrm{MgSO}_{4}(20)$. Importantly, $\mathrm{Mg}$ intoxication was not seen in patients receiving the "Magpie protocol" (5).

Three maternal deaths occurred among the $19 \mathrm{Mg}$ intoxicated women, but the cause of maternal death was not directly related to the Mg level. The cause of death in these three cases was: septic shock, thyroid crisis, and intracerebral hemorrhage. Serum Mg level in these three cases had normalized a couple of days before they died. Lowe et al. reported no maternal death in their large systematic review, while Duley 
Table 4. Perinatal outcomes of cases versus controls.

\begin{tabular}{lcccc}
\hline & $\begin{array}{c}\text { Cases } \\
\mathrm{n}=19\end{array}$ & $\begin{array}{c}\text { Controls } \\
\mathrm{n}=166\end{array}$ & $p$ value & $\begin{array}{c}\text { OR } \\
(95 \% \mathrm{Cl})\end{array}$ \\
\hline $\begin{array}{c}\text { Baby sex } \\
\text { Male }\end{array}$ & $13(68.4 \%)$ & $79(50.3 \%)$ & & $\mathrm{NA}$ \\
$\quad \begin{array}{l}\text { Female } \\
\text { Baby Birthweight }\end{array}$ & $6(31.6 \%)$ & $78(49.7 \%)$ & 0.131 & $\mathrm{NA}$ \\
$\begin{array}{c}\text { Apgar Score } \\
\text { Minutes 1 }\end{array}$ & $1516.67+565.015$ & $1872.32+662.860$ & $0.005^{*}$ & $\mathrm{NA}$ \\
$\quad$ Minutes 5 & $2.75+2.179$ & $5.57+2.250$ & $0.000^{*}$ & $\mathrm{NA}$ \\
$\begin{array}{c}\text { SGA } \\
\text { Yes }\end{array}$ & $5.42+1.782$ & $7.34+1.573$ & $0.000^{*}$ & 3.74 \\
$\quad$ No & $6(31.6 \%)$ & $14(8.4 \%)$ & $0.002^{*}$ & $(2.66-11.38)$ \\
$\begin{array}{c}\text { Perinatal Death } \\
\text { Yes }\end{array}$ & $13(68.4 \%)$ & $152(91.6 \%)$ & & 5.56 \\
No & $7(36.8 \%)$ & $11(6.6 \%)$ & $0.000^{*}$ & $(2.29-5.94)$ \\
\hline
\end{tabular}

et al. found two trials reported maternal deaths $(8,20)$. The highest serum $\mathrm{Mg}$ level found among the cases in the current study was $25.6 \mathrm{mg} / \mathrm{dL}$, this level is not considered to be high enough to directly cause maternal death. With serum levels of $20-34 \mathrm{mg} / \mathrm{dL}, \mathrm{Mg}$ intoxication will be manifest as hypoventilation, acidosis, loss of tendon reflexes, and general weakness. Severe and life-threatening complications like respiratory depression and cardiac arrest will occur with the serum levels of $48-72 \mathrm{mg} / \mathrm{dL}$ (8). The clinical signs and symptoms in these $\mathrm{Mg}$ intoxication cases were general muscle weakness (loss of patellar reflex), loss of consciousness, and respiratory distress. The overall incidence of loss of patellar reflexes, loss of consciousness, and respiratory depression among all 1743 patients receiving $\mathrm{MgSO}_{4}$ treatment was, respectively, $0.4 \%$ (8 cases), $0.5 \%$ (9 cases), and $0.1 \%$ (2 cases). The side effects caused by $\mathrm{MgSO}_{4}$ treatment found in this study were significantly lower compared with the large systematic review by Lowe et al. (8). This review is comparable to our study since the research sample was only taken from middle- and low-income countries. The overall incidence of loss of patellar reflexes and respiratory distress in this systematic review was $1.2 \%$ and $1.3 \%$ (8). Unfortunately, this review did not evaluate the clinical sign of loss of consciousness. Perhaps this sign is not commonly interpreted as one of the major manifestations of $\mathrm{Mg}$ intoxication. The possible explanation of the much higher incidence of side effects reported in Lowe et al. (8) review compared with our study may be related to the regimen choices. Only eight studies used the Zuspan regimen (which is the same regimen used in our hospital) (18), while the other studies used the Pritchard (19) or the Dhaka regimens (21) with a relatively higher total dose of $\mathrm{MgSO}_{4}$. Administration of $\mathrm{MgSO}_{4}$ longer than 24 hours and a total dose of more than 24 grams would be potentially hazardous for the maternal outcome, as seen in the current study.

Interestingly, intramuscular administration of $\mathrm{MgSO}_{4}$ was associated with a doubling of the rate of $\mathrm{Mg}$ intoxication; $52.6 \%$ of patients in the case group received $\mathrm{MgSO}_{4}$ intramuscular versus $21.8 \%$ in the control group $(p=0.004)$. Similar findings have been reported by Kanti et al. (21); these authors reported a higher rate of signs and symptoms indicative of $\mathrm{Mg}$ intoxication and local site complications to be associated with intramuscular $\mathrm{Mg}$ administration. The Magpie trial also showed that intravenous administration had fewer side effects compared with the intramuscular route (5).

In the current study, the majority of the cases received intramuscular $\mathrm{MgSO}_{4}$, since most of these patients were referred from primary health centers or primary health care or rural areas. This is in line with the regional referral guidelines on the management of PESF. Our regional policy for community-based care (primary health care) is to give a loading dose following the Pritchard regimen as initial management of PESF, before transferring the patients to a tertiary center. This approach has been implemented in many low- and middle-income countries such as Bangladesh, and India (22). The majority of smaller Indonesian medical centers prefer Pritchard IM administration regimen because of ease of administration, non-availability of infusion set/syringe pump, lack of nursing staff, and the fact that intramuscular administration is more costeffective compared with iv regimen (23). Encouraging the government to provide syringe-pump availability throughout the nation could potentially improve outcomes in Indonesian women with PESF.

In our tertiary referral center, $\mathrm{MgSO}_{4}$ is given via an intravenous route (syringe pump infusion) following the Zuspan regimen $(18,22)$. Maintaining the therapeutic level of $\mathrm{Mg}$ while monitoring for sign of $\mathrm{Mg}$ 
intoxication is important. Simple clinical assessment is adequate in most PESF women treated with $\mathrm{MgSO}_{4}$, and more suitable in low- and middle-income countries $(5,12,22)$, as is also demonstrated by the low overall rate of just over $1 \%$ in the current series.

The incidence of eclampsia and HELLP syndrome was significantly higher in the case group, while unexpectedly acute pulmonary edema, a common PE complication in Indonesia (15) was not seen among the $19 \mathrm{Mg}$ intoxication cases. The presence of these complications may represent a significant risk factor of $\mathrm{Mg}$ intoxication due to the clinical necessity for a more prolonged $\mathrm{MgSO}_{4}$ administration. Among the cases, more women received $\mathrm{MgSO}_{4}$ for more than 5 days compared with the controls, although the average length of hospital stay between both groups did not differ significantly (cases versus controls: $10.21 \pm 8.43$ versus $11.29 \pm 15.20, p=0.783)$. The study results appear to indicate that giving $\mathrm{MgSO}_{4}$ for more than 24 hours is not advisable unless $\mathrm{Mg}$ levels can be checked at regular intervals.

Another significant risk factor that could be contributing to the occurrence of $\mathrm{Mg}$ intoxication is oliguria and renal insufficiency. In this series, Mg-intoxicated patients had a worse renal function, reflected by higher BUN and serum creatinine level. Almost all of the serum magnesium is cleared by renal excretion, so any problems of urine production will significantly increase the risk of magnesium intoxication (6).

All patients in the $\mathrm{Mg}$ intoxicated group received calcium gluconate therapy as immediate management in line with our national protocol. This routine intervention is not found in the large systematic review by Lowe et al. The use of calcium gluconate in their review was extremely rare $(0.18 \%)$. There is no clear explanation of this finding. However, Lowe et al. assumed that the low use of calcium gluconate reflects an infrequent need for its use as an antidote, rather than the unavailability of the drugs in the hospital $(8,24)$.

The case had a higher rate of perinatal death, SGA, and low Apgar scores. Seven perinatal deaths (4 fetal demise) (36.8\%) occurred in Mg-intoxicated group compared with 11 deaths (6.6\%) in the control group. The higher rate of SGA in the case group reflects disease severity. About one-third of the cases were delivered of neonates who developed respiratory distress syndrome (RDS), significantly different from the $4 \%$ in the control group. Low Apgar scores were also more prominent among cases, in line with the strong correlation between maternal and fetal $\mathrm{Mg}$ levels resulting in respiratory muscle suppression and general muscle weakness. Previously, the use of antenatal $\mathrm{MgSO}_{4}$ was discouraged by the majority of neonatologists because of a perceived risk of neonatal respiratory depression (25). However, recent studies with a large number of subjects have shown that particular concerns regarding the use of antenatal $\mathrm{MgSO}_{4}$ for adverse neonatal implications were only encountered after long duration of $\mathrm{Mg}$ administration (26). We also discourage the prolonged use of antenatal $\mathrm{MgSO}_{4}$ in PESF cases, not only because of the aforementioned neonatal concern but also because of the association with an increased risk of maternal and perinatal complications. The meta-analytic study by Duley et al. did not find any difference in the risk of stillbirth or neonatal death, but there was a small increase in the overall risk of perinatal mortality associated with $\mathrm{MgSO}_{4}$ use (RR 1.04) (27).

\section{Conclusion}

$\mathrm{Mg}$ intoxication was found in just over 1\% of PESF women treated with $\mathrm{MgSO}_{4}$, as was found to be associated with a significant risk to the mother and fetus. While Mg serum levels cannot be measured as a routine in many developing countries, serial monitoring for the simple clinical signs and symptoms indicative of $\mathrm{Mg}$ intoxication is effective as a monitoring tool. In these countries, $\mathrm{Mg}$ serum level monitoring is indicated in patients requiring longer duration and higher accumulated doses of $\mathrm{MgSO}_{4}$, both carry a high risk of $\mathrm{Mg}$ intoxication.

\section{Acknowledgments}

We thank Prof. Dr. Hendy Hendarto dr. SpOG(K) as the head of department who supported and gave permission to perform this study; we thank all staff in Department Obstetrics \& Gynecology Faculty of Medicine Universitas Airlangga - RSUD Dr. Soetomo - RS Universitas Airlangga for their genuine support for this study; we thank our resident in training and the research team for their hard work in collecting data in this study; and we would like to thank all the patients who were involved in this study, without their participation the study could never be completed.

\section{Disclosure statement}

The authors declare no conflict of interest.

\section{ORCID}

Muhammad Ilham Aldika Akbar (1) http://orcid.org/00000002-2003-9282

Muhammad Adrianes Bachnas (ib) http://orcid.org/0000-00021710-3909

Ernawati (i) http://orcid.org/0000-0002-9344-3606 


\section{References}

[1] Tranquilli AL, Dekker G, Magee L, et al. The classification, diagnosis and management of the hypertensive disorders of pregnancy: A revised statement from the ISSHP. Pregnancy Hypertens. 2014;4(2):97-104.

[2] DULEY L. Maternal mortality associated with hypertensive disorders of pregnancy in Africa, Asia, Latin America and the Caribbean. BJOG An Int J Obstet Gynaecol. 1992;99(7):547-553.

[3] Ilham M, Akbar A, Adrianes Bachnas M, et al. The massive problem of preeclampsia in indonesia: in need of a redesigned national health care system. Pregnancy Hypertens. 2018;13(1):S16

[4] ACOG. Hypertension in pregnancy. Obs Gynecol. 2013;122(5):1122-1131.

[5] Altman D, Carroli G, Duley L, et al. Do women with pre-eclampsia, and their babies, benefit from magnesium sulphate? The Magpie trial: a randomised placebo-controlled trial. Lancet. 2002;359(9321):187790.

[6] Tannirandorn Y. Is magnesium sulfate for prevention or only therapeutic in preeclampsia? J Med Assoc Thail. 2005;88(7):1003-10

[7] Sibai BM, Gary Cunningham F. Prevention of preeclampsia and eclampsia [Internet]. Fourth Edn. In: Chesley's Hypertens. Disord. Pregnancy. Elsevier Inc.; 2009. DOI:10.1016/B978-0-12-407866-6.00012-2

[8] Lowe RF, Smith JM, Felker-Kantor E, et al. An integrative review of the side effects related to the use of magnesium sulfate for pre-eclampsia and eclampsia management. BMC Pregnancy Childbirth. 2013;13:1-11.

[9] Tukur J. The use of magnesium sulphate for the treatment of severe pre-eclampsia and eclampsia. Ann Afr Med. 2009;8(2):76.

[10] Gröber U, Schmidt J, Kisters K. Magnesium in prevention and therapy. Nutrients. 2015;7(9):8199-8226.

[11] Jackson CB, Drobatz KJ. Iatrogenic magnesium overdose: 2 Case reports. J Vet Emerg Crit Care. 2004;14 (2):115-123.

[12] Grissinger M. Preventing magnesium toxicity in obstetrics. Pharm Ther [Internet]. 2009;34. Available from. https://www.ncbi.nlm.nih.gov/pmc/articles/ PMC2799127/pdf/ptj34_8p403.pdf

[13] Ernawati, Gumilar E, Kuntoro, Soeroso J, Dekker G. Expectant management of preterm preeclampsia in Indonesia and the role of steroids. J Matern Neonatal Med. 2016;29:1736-1740.

[14] Kartika AR, Aldika Akbar MI, Umiastuti P. Risk factor of severe preeclampsia in Dr. Soetomo Hospital Surabaya in 2015. Maj Obstet Ginekol. 2017;25(1).

[15] Wardhana MP, Dachlan EG, Dekker G. Pulmonary edema in preeclampsia: an Indonesian case-control study. J Matern Neonatal Med. 2018;31(6):689-695.
[16] Cunningham FG, Roberts JM, Lindheimer MD. The clinical spectrum of preeclampsia [Internet]. Fourth Edi. In: Chesley's Hypertens. Disord. Pregnancy. Elsevier Inc.; 2009. DOI:10.1016/B978-0-12-4078666.00002-X

[17] Muiesan ML, Salvetti M, Lorenza M, et al. An update on hypertensive emergencies and urgencies An update on hypertensive emergencies and urgencies Pietro Scicchitano i, Enrico Agabiti Rosei a, Roberto Pedrinelli $n$, on behalf of the Working Group on Hypertension, Prevention, Rehabilitation of. 2015;

[18] Zuspan FP. Problems encountered in the treatment of pregnancy-induced hypertension. A point of view. Am J Obstet Gynecol. 1978;131(6):591-597.

[19] Pritchard JA, Cunningham FG, Pritchard SA. The Parkland memorial hospital protocol for treatment of eclampsia: evaluation of 245 cases. Am J Obstet Gynecol. 1984;148(7):951-963.

[20] Duley L, Am G, Dj H Magnesium sulphate and other anticonvulsants for women with pre-eclampsia (Review). Cochrane Collab. 2003;

[21] Begum R, Begum A, Johanson R, et al. A low dose ("Dhaka") magnesium sulphate regime for eclampsia. Acta Obstet Gynecol Scand. 2001;80(11);9981002.

[22] Gordon R, Magee LA, Payne B, et al. Magnesium sulphate for the management of preeclampsia and eclampsia in low and middle income countries: a systematic review of tested dosing regimens. J Obstet Gynaecol Canada [Internet]. 2014;36 (2):154-163.

[23] Kanti V. Comparision between intramuscular and intravenous regimen of magnesium sulfate in management of severe pre-eclampsia and eclampsia. Int J Reprod Contraception Obstet Gynecol. 2015;4:1.

[24] Ridge AL, Bero LA, Hill SR. Identifying barriers to the availability and use of magnesium sulphate injection in resource poor countries: A case study in Zambia. BMC Health Serv Res. 2010;10(1). DOI:10.1186/1472-696310-340

[25] Levene M, Blennow M, Whitelaw A, et al. Acute effects of two different doses of magnesium sulphate in infants with birth asphyxia. Arch Dis Child. 1995;73 (3):174-177.

[26] M R, P PG. A review of the role for magnesium sulphate in preterm labour [Internet]. BJOG An Int J Obstet Gynaecol. 2005;84-88. Available from http://www.embase.com/search/results? subaction=view record\&from=export\&id=L40313989

[27] Duley L, Farrell B, Armstrong N, et al. The Magpie Trial: A randomised trial comparing magnesium sulphate with placebo for pre-eclampsia. Outcome for children at 18 months. BJOG An Int J Obstet Gynaecol. 2007;114:289-299. 